\title{
SANTO TOMÁS DE AQUINO NA AMORIS LAETITIA: REPROPONDO UMA ANTROPOLOGIA TEOLÓGICA DA
} \author{
ALEGRIA \\ St Thomas of Aquinas in Amoris Laetitia: Reproposing a Theological Anthro- \\ pology of Joy
}

André Luiz Boccato de Almeida *

RESUMO: O presente artigo tem como escopo analisar as frequências e incidências do pensamento ético teológico do grande doutor dominicano, Santo Tomás de Aquino, na exortação pós-sinodal Amoris Laetitia (AL). As dezenove (19) citações no texto conclusivo sugere-nos que no seu pensamento se encontra um resgate sólido, sábio, prudente e sereno de uma tradição a ser revisitada sempre e que nos propicia pensar em uma verdadeira antropologia teológica da alegria. O objetivo é o de repropor uma teologia do matrimônio que encontra seu enraizamento em uma visão do amor fecundo, mais que em uma concepção jurídico canônica. A reflexão discorrerá em dois momentos. No primeiro, se apresentará a moral matrimonial presente em Amoris Laetitia (AL) com as implicações próprias. No segundo, propõe-se a analisar cada número citado do pensamento de Santo Tomás na exortação de Francisco, mostrando as mudanças de posturas morais propostas por este magistério. Enfim, na conclusão sintetizaremos as ideias mais relevantes do artigo. $\mathrm{O}$ resultado a ser obtido é o de demonstrar que a exortação pós-sinodal não apenas avança em uma postura moral, mas também repropõe a antropologia teológica de Santo Tomás como referencial para o debate teológico, abrindo a possibilidade de uma nova forma de acompanhar pastoralmente os casais e as famílias a partir da experiência do amor humano e suas possíveis variações ao longo da vida.

PALAVRAS-CHAVE: Santo Tomás de Aquino. Amor. Alegria. Discernimento. Acompanhamento.

ABSTRACT: The purpose of this article is to analyze the frequency and occurrences of the theological ethical thinking of the great Dominican doctor, St. Thomas Aquinas, in the post-synodal exhortation Amoris Laetitia ( $A L$ ). The nineteen (19)

* Pontifícia Universidade Católica de São Paulo (PUC-SP), São Paulo, Brasil. 
quotations in the concluding text suggest that, in his thinking, there is a solid, wise, prudent and serene tradition, always to be revisited, that allows us to think of a true theological anthropology of joy. The purpose is to re-examine a theology of marriage that finds its roots in a vision of fruitful love, rather than in a canonical juridical conception. The reflection will be presented in two moments. In the first, the marital morality present in Amoris Laetitia $(A L)$ will be discussed with its own implications. In the second, we propose to analyze each number quoted from the thought of St. Thomas in the exhortation of Francis, showing the changes of moral postures proposed by this magisterium. Finally, in the conclusion, we will synthesize the most relevant ideas of the article. The result sought is to demonstrate that the post-synodal exhortation not only shows progress in terms of moral posture, but also re-proposes the theological anthropology of St. Thomas as a reference for the theological debate. This opens the possibility of a new way of accompanying couples and families pastorally, based on the experience of human love and its possible variations throughout life.

KEYWORDS: Saint Thomas Aquinas. Love. Joy. Discernment. Accompaniment.

\section{Introdução}

Diante de inúmeras incompreensões por parte de grupos eclesiais em aceitar a nova forma de método e epistemologia teológica no que se refere ao tema do amor, da família e da moral matrimonial, o Papa Francisco em seu texto conclusivo das duas sessões do Sínodo dos Bispos, insere sabiamente 19 importantes citações de Santo Tomás que proporcionam uma revisitação de uma tradição teológico-moral esquecida.

Para isso, propomos esta reflexão a partir de dois pontos. No primeiro, situar brevemente a teologia moral matrimonial presente em Amoris Laetitia (AL). No segundo, analisar as citações atribuídas a Santo Tomás presentes no contexto da exortação pós-sinodal, salientando a atualidade de um sadio retorno à teologia de Santo Tomás na reflexão ético-teológica do texto pontifício, concluindo com uma possível análise das questões levantadas.

Vemos como necessário salientar a pertinência e atualidade de Amoris Laetitia como fruto maduro do processo sinodal de escuta, diálogo e problematização das realidades das famílias no contexto contemporâneo. Santo Tomás torna-se uma baliza segura para repropor de forma atualizada o dinamismo do amor no matrimônio.

\section{Qual moral matrimonial presente em Amoris Laetitia?}

A exortação pós-sinodal AL de Francisco assume os resultados dos dois sínodos sobre a família, o de 2014 e o de 2015. Além de qualquer visão 
simplista sobre a realidade matrimonial e a crise que envolve a família e as novas configurações hoje, o olhar da exortação parte de uma realidade concreta sobre a situação das pessoas envolvidas na instituição matrimonial. $\mathrm{O}$ texto, mesmo sendo um posicionamento sério e longo do magistério pontifício, longe de exaurir as questões debatidas nas sessões sinodais, pede a reflexão dos pastores e dos teólogos.

A moral matrimonial presente em AL é construída à luz do processo de sinodalidade, expressão marcante do atual magistério pontifício. Sem diminuir o significado da rica e longa tradição sacramental e doutrinal do matrimônio, edificado ao longo dos séculos, a exortação em questão tem como referência uma impostação ético-moral que privilegia o tema do amor (AL, nn. 9-10) ${ }^{1}$, pois a sensibilidade pastoral em questão obriga-nos a compreender e distinguir em profundidade a forma e o conteúdo da doutrina. Francisco, após ouvir e analisar o conjunto das intervenções dos Padres Sinodais, comparou as inúmeras referências a um poliedro (AL, n. 4), ou seja, há uma marca de complexidade que força a uma reflexão magisterial mais sofisticada.

$\mathrm{Na}$ presente exortação, o amor e os seus dinamismos estão na base para uma melhor explicitação sobre o que é o fundamento do matrimônio e da família. Esta impostação explicitada ao longo dos números, chamam-nos a atenção para a necessidade de retornar a uma hermenêutica teológica que leve em consideração a realidade concreta do casal e dos filhos, e mais, a qualidade da experiência de verdadeiro amor, fundamento da indissolubilidade (VESCO, 2015).

Neste sentido, o amor ou a caridade, fonte da sacramentalidade matrimonial, impõe-se como uma dimensão moral que se exprime em um processo de amadurecimento de contínuo crescimento (AL, n. 134). Toda a moral matrimonial presente na exortação insiste em um trabalho pastoral para assegurar o crescimento do amor. Como a teologia do matrimônio, nos dois últimos séculos, esteve decididamente marcada por uma impostação mais de caráter juridicista-canônico que teológico-pastoral, notamos que a exortação AL, seguindo as indicações do Vaticano II e dos desdobramentos posteriores, e em especial a Familiaris Consortio (FC), quer repropor uma expressão que assuma a impostação e a sensibilidade contemporâneas.

A moral matrimonial presente nas longas e profundas reflexões que Francisco faz é devedora de toda uma rica teologia bíblica, patrística e dos grandes teólogos que avistaram na conjugalidade (GS, n. 49-51) e na esponsabilidade (PÉREZ-SOBA, 2010, p. 92-95) a centralidade do amor dos esposos, enraizados no mistério de comunhão trinitária, que tem no amor

\footnotetext{
${ }^{1}$ Esta impostação sobre o tema do amor e da alegria na vida matrimonial é salientada em uma análise articulada à exortação.
} 
sua expressão máxima. Se o amor é a norma normans da indissolubilidade matrimonial convém destacar que necessitamos aprofundar esta realidade dinâmica, complexa e profunda. Encontramos, então, na redação de AL a presença de Santo Tomás que nos ajuda a compreender, em citações decisivas, qual é a estrutura e o mecanismo antropológico do amor humano, expressão do amor divino no coração humano.

Nota-se que o itinerário das duas sessões sinodais que antecederam a elaboração e redação da Amoris Laetitia $(A L)$, foi marcado por uma sensibilização de teólogos e pastores na busca por uma melhor elucidação dos problemas que envolvem a família ${ }^{2}$ em suas realidades concretas (BOZZOLO et al., 2015). Além disso, o próprio papa Francisco desejou que o caminho sinodal possibilitasse alargar a perspectiva e reavivar a consciência sobre a importância do matrimônio e família, levando a um aprofundamento de questões doutrinais, morais, espirituais e pastorais (AL, n. 2).

O problema que se coloca, no contexto da teologia do matrimônio, é o de um não desdobramento pastoral adequado devido à sua implicação canônica sem uma teologia do amor de cunho personalista e pastoral. No Vaticano II, com a síntese própria da Constituição Pastoral Gaudium et Spes (GS, n. 47-52), houve um esforço em reequilibrar o excesso jurídico dos últimos séculos, com os avanços e descobertas provenientes a partir de uma perspectiva personalista. Embora tenhamos na exortação pós-sinodal Familiaris Consortio (FC) de João Paulo II um modo próprio de abordar pastoralmente a situação da vida familiar com as conhecidas situações irregulares, percebemos que é em Amoris Laetitia que de fato é assumido pelo magistério pontifício a perspectiva do amor enquanto um processo gradual e do acompanhamento das famílias na pastoral, na tentativa de superar o dualismo: objetividade e subjetividade do valor moral.

Neste sentido, nota-se que esta mudança de perspectiva advém da lúcida constatação segundo a qual, na Igreja, é uma unidade de doutrina e práxis, mas isto não impede que existam maneiras diferentes de interpretar alguns aspectos da doutrina ou algumas consequências que decorrem dela (AL, n. 3). Esta impostação presente na exortação, proveniente das duas sessões sinodais, leva-nos a crer que houve uma tentativa de recentrar a doutrina sacramental do matrimônio e da família mais propriamente no amor que na disciplina eclesiástica, embora esta não seja dispensada.

Sob este ângulo, notamos que Francisco admite que durante muito tempo, pensou-se que com simples insistências em questões doutrinais, bioéticas e morais, sem motivar a abertura à graça, já se dava um bom apoio às famílias. Para ele há ainda certa dificuldade em apresentar o matrimônio mais como um caminho dinâmico de crescimento e realização do que

\footnotetext{
${ }^{2}$ Basta constatar o contributo dos teólogos e suas discussões acadêmicas.
} 
como um fardo a carregar a vida inteira. A esta constatação soma-se também o fato de que custa deixar espaço à consciência dos fiéis, que muitas vezes respondem da melhor forma que podem ao Evangelho no meio dos seus limites e são capazes de realizar o seu próprio discernimento perante situações em que se rompem todos os esquemas (AL, n. 37). Enfim, o pontífice diz: "somos chamados a formar as consciências, não a pretender substituí-las" (AL, n. 37).

A partir desta impostação vemos a mudança de paradigma. Francisco problematiza acerca da essência da vida matrimonial. Não nega os inúmeros problemas sociais, culturais e religiosos vividos pela família, contudo, busca encontrar no amor a ser construído a essência da experiência humana e sacramental. Para isso, observamos que ele retoma na exortação a tradição teológica de Santo Tomás que vê na realidade do amor mais um caminho dinâmico de crescimento e realização do que um fardo a carregar a vida inteira. As relevantes citações do Aquinate, que nos propomos a analisar, pretendem ser a verificação, a partir da própria tradição teológica ocidental, de que é possível repropor uma antropologia teológica da alegria como caminho possível diante de uma perspectiva apenas canônico-disciplinar. Mais que reduzir o dinamismo do amor a ser vivido pela família de modo alegre ("Amoris Laetitia") em questões de nulidade canônica, pela teologia dinâmica do amor de Santo Tomás, pretende prevenir e propor um caminho que exige um acompanhamento sério e pastoral por parte da Igreja.

\section{Santo Tomás na Amoris Laetitia: assimilação, integração e atualização}

A presença de Santo Tomás de Aquino na exortação pós sinodal - 19 vezes ao todo - tem a sua total pertinência dentro de um horizonte teológico do matrimônio, da família e da realidade do amor. A questão que nos envolve, neste intuito de analisar um texto do magistério atual, é a de fazer perceber como um pensador-teólogo medieval, que compreendeu a realidade humana direcionada pela vida da graça no dinamismo teologal, pode nos ajudar a captar o significado da realidade humana com as suas circunstâncias.

Queremos aqui mencionar todas as citações tomasianas presentes no texto, destacando a teologia emergente. Sabemos que o pensamento de Santo Tomás necessita ser compreendido no seu horizonte teológico histórico, contudo, aqui, queremos destacar apenas os textos usados para captar a sua assimilação, integração e atualização no todo da exortação. A grande totalidade das citações advém da sua obra mais conhecida, a Suma de Teologia. Ali, ele considera o homem enquanto imagem de Deus e capaz de 
retornar a Deus. Ele trata sobre o amor e as paixões a partir de um olhar teológico aberto à uma percepção antropológica, própria de sua época. Santo Tomás foi o "primeiro a elaborar um grande tratado sobre as paixões e sobre o amor" (PHILIPPE, 1999, p. 98) ${ }^{3}$. Vejamos a frequência e o seu significado no interior do texto da exortação pós-sinodal.

Nota 108: "todo o ser humano está obrigado a ser afável com aqueles que o rodeiam" (TOMÁS, S.Th. II-II, q. 114, art. 2, ad 1.) . Esta é a primeira citação de Santo Tomás na exortação e situa-se no capítulo IV "O amor no matrimônio". O papa no texto está fazendo uma análise sobre o tema da amabilidade. Ele parte da ideia segundo a qual a vida do cristão é plasmada pela experiência do amor que a integra e assume em sua inteireza. Esta questão 114 da Suma de Teologia versa sobre a amizade ou a afabilidade ("De amicitia seu affabilitate") que está no tratado da Justiça. Nesta questão em particular, Santo Tomás coloca a amizade ou a afabilidade no horizonte das relações sociais; eis porque no tratado da justiça. O doutor dominicano, na verdade, relê Aristóteles a quem comenta, elogiando a amizade, e desenvolve a doutrina numa perspectiva propriamente ética, atenta ao que convém à dignidade, à felicidade da pessoa e à vida social. A citação 108 da exortação vem propriamente do artigo 2 da questão 114, "Esta amizade é parte da justiça" ("Utrum huismodi amicitia sit pars iustitiae"). A relação encontra-se justamente entre a amizade e a justiça. Na verdade, Santo Tomás afirma que o ser humano está obrigado a ser afável com aqueles que o rodeiam, partindo da sua interpretação de Aristóteles, segundo o qual, "ninguém consegue passar um dia inteiro com uma pessoa triste e sem atrativos"

Esta percepção própria de Santo Tomás foi aprofundada por Bernard (1985, p. 23s), quando aprofundando a ideia de afetividade, percebe que a afabilidade é orientada em direção ao exterior, mas é expressão do estado interior do sujeito. $\mathrm{O}$ fato de o sujeito estar obrigado a ser afável com os que o rodeiam leva a compreender o movimento afetivo como um processo complexo (BERNARD, 1985, p. 24). Então, não são os sentimentos apenas que são complexos mas o sujeito que os vive em sua condição presente e real. A vida matrimonial, neste sentido, é o contexto propício onde os sujeitos envolvidos são chamados a amadurecerem os afetos de modo dialogante.

\footnotetext{
${ }^{3}$ Esta reflexão foi aprofundada por Philippe (1999, p. 92-107), que faz uma sintética análise acerca das principais correntes ocidentais, destacando no capítulo $\mathrm{V}$, a especificidade da abordagem de Santo Tomás.

${ }^{4}$ A citação completa do texto latino apresenta-se assim: "Et ideo homo tenetur ex quodam debito naturali honestatis ut homo aliis delectabiliter convivat: nisi propter aliquam causam necesse sit aliquando alios utiliter constristare". (Seguiremos esta edição da Suma para todas as citações). ${ }^{5} \mathrm{O}$ texto de Aristóteles que é o Comentário à ética Nicomaqueia, na sua versão latina, assim se apresenta: "nullus potest per diem morari cum triste, neque cum non delectabili".
} 
A concepção de amabilidade que o papa Francisco resgata de Santo Tomás é compreensível, pois na vida matrimonial ela é um desejo profundo que o casal encontra em querer partilhar a vida com afabilidade em uma relação ou vínculo de estreito laço social. O tratado da justiça no Aquinate, um aprofundamento ético-teológico de Aristóteles, caracteriza-se pela busca da 'essência' do que une as pessoas entre si. A amizade e amabilidade, por trazerem bem-estar social, aproximam as pessoas, dando a base para a vida social e a alegria.

Notas 110 e 111: "ser mais próprio da caridade querer amar do que querer ser amado (e que de fato) as mães, que são as que mais amam, procuram mais amar do que ser amadas" (TOMÁS, S.Th. II-II, q. 27, art. 1, ad. 2.) ${ }^{6}$. São duas citações de Santo Tomás em continuidade, dentro ainda do capítulo IV "O amor no matrimônio". Estas citações do nosso doutor colocam-se dentro da questão 27 que trata acerca do "Ato principal da caridade: o amor" ("De principali actu caritatis, qui est dilectio"). As duas citações fazem parte do artigo 1 que se refere à interessante pergunta: "É mais próprio da caridade ser amado, ou amar?" ("Utrum caritatis sit magis proprium amari quam amare"). Este primeiro artigo da questão 27 questiona que tipo de afeição constitui o ato de amor. A preocupação central de Santo Tomás dá-se em precisar o que é o amor. A sua conclusão é a de que amar é próprio da caridade. Para o doutor dominicano, a caridade é, diferentemente de nós contemporâneos, um amor sobrenatural na origem (suscitado em nós pelo Espírito Santo), no fim (enquanto se ama a Deus como ele ama a si mesmo), e como participação na sua mesma natureza (como participação no amor divino). Sendo assim, a caridade não é simplesmente expressão de qualquer amor (eros ou philia), mas do amor que vem infundido no coração do ser humano pela graça de Deus (ágape).

Esta abordagem de Santo Tomás é uma continuação da ideia agostiniana do amor como desejo ou apetite ${ }^{7}$. Ele segue esta tendência segundo a qual quem ama, no caso as mães, após serem possuídas por este amor, o desejo pode acabar, a não ser que exista o perigo de perder o que foi adquirido. Nesse caso, o desejo de possuir (habendi) transforma-se em medo de perder (mettus amittendi) (ARENDT, 1998, p. 16-17). As mães fazem esta experiência de amarem e desejarem tanto seus filhos que surge junto um sentimento de perda fazendo-as se sentir ora impotentes ora potentes diante do amor.

O papa Francisco, comentando o texto de 1Cor 13 - no que se refere ao desprendimento - recorre à autoridade teológica de Santo Tomás para afirmar que o verdadeiro amor, solidificado em Deus, deveria nos levar a

\footnotetext{
${ }^{6}$ A citação completa do texto latino apresenta-se assim: “(...) Amari autem non est actus caritatis ipsius qui amatur: sed actus caritatis eius est amare (...) quia matres, quae máxime amant, plus querunt amare quam amari".

${ }^{7}$ Esta ideia foi aprofundada por ARENDT, 1997, 189 p.
} 
um esvaziamento dos nossos interesses, pois é um ato de Deus no interior da pessoa que a faz mais amar que ser amado. Eis o motivo pelo qual o próprio teólogo dominicano usa o exemplo da mãe como as que mais amam. Elas, na verdade, mais amam porque pouco necessitam ser amadas diante do ato de amor que as levam a amar os filhos. A única e verdadeira alegria das mães é amar seus filhos, o que é expressão da participação ativa na caridade divina. A alegria verdadeira que irrompe nos corações dos casais brota desta forma de dedicação total ao outro, expressão da conjugalidade e da indissolubilidade matrimonial.

Nota 115. Esta citação que Francisco usa na exortação é uma referência ao amor - "força de união" ("vis unitiva") - presente no próprio ser de Deus (TOMÁS, S.Th. I, q. 20, art. 1 ad 3.) ${ }^{8}$. A questão 20 é o conhecido "O amor de Deus" ("De amore Dei"). O artigo 1ํ intitula-se "Existe amor em Deus?" ("Utrum amor sit in Deo"). Nesta interessante questão, Santo Tomás desenvolve a ideia segundo a qual o amor é o ato primeiro da vontade e do apetite. Na verdade, o teólogo tenta demonstrar neste artigo que "amar alguém propriamente é querer para ele o que é bom" (TOMÁS, S.Th. I, q. 20, art. $1 \mathrm{ad} 3.)^{9}$. Ora, se amar alguém é querer o bem, o desejo de quem ama é se unir profundamente ao objeto deste amor. Este vínculo afetivo é, para Santo Tomás, o próprio amor. Então, amar o outro, seja Deus ou uma pessoa, é estar afetivamente ligado ou vinculado como que em uma atração para o próprio bem.

Na abordagem do Aquinate, o amor como mistério que une o casal de forma misteriosa encontra ressonância no hino à caridade de Paulo (1Cor 13), compreendido como uma realidade sacramental que eleva o amor à ordem da graça. Esta ideia pode ser compreendida do seguinte modo:

(...) A união matrimonial representa, de tal modo, a inauguração de um novo modo de ser casal não mais centrado sobre si mesmo, sobre o egoísmo ou a rivalidade enquanto consequência do pecado das origens, mas sobre a submissão comum a Cristo, início de uma nova humanidade que se tornou "una" em Cristo, salvador do seu corpo (ROCCHETTA, 2011, p. 83).

O Papa Francisco retoma esta visão sacramental sobre a essência do amor para dizer que este mistério que une os esposos é uma expressão sobrenatural. É um amor que santifica, enriquece e ilumina a vida matrimonial dos que são atraídos. Esta teologia do amor de Santo Tomás, em sua profunda e eficaz linguagem, está na base para compreender a teologia moral matrimonial. A caridade conjugal, portanto, encontra neste vínculo profundo de atração - força de união - o seu sentido teológico. É

\footnotetext{
${ }^{8}$ Francisco refere-se a Santo Tomás quando este demonstra nesta questão e artigo que o amor não é propriamente o ato a ser realizado, mas a "força de união" ("vis unitiva") que está presente no próprio Deus.

${ }^{9}$ A citação latina assim se expressa: "Hoc enim est proprie amare aliquem, vele ei bonum".
} 
urgente, portanto, colocarmos esta ideia que é central na preparação dos nossos noivos e noivas.

Nota 116: a presente citação de Santo Tomás refere-se ao amor enquanto uma "união afetiva" (TOMÁS, S.Th. II-II, q. 27, art. 2). O contexto dela na exortação dá-se a partir da afirmação segundo a qual o amor presente na vida dos cônjuges é fruto de união profunda sendo espiritual e oblativa, que reúne em si a ternura da amizade e a paixão erótica. O doutor dominicano, neste artigo da Suma de Teologia, responde à seguinte questão, próprio do artigo $2^{\mathrm{o}}$ : "O amor, enquanto ato da caridade, é idêntico à benevolência?" ("Utrum amare, secundum quod est actus caritatis, sit idem quod benevolentia"). Neste artigo, no horizonte da ideia de caridade e do amor, Santo Tomás esforça-se por dar uma fundamentação racional e ontológica à experiência humana do amor. Para ele, a benevolência é "um ato da vontade que consiste em querer o bem a outrem"10. No Aquinate, quando comenta Aristóteles, há uma diferença na expressão do ato de amor. Há uma primeira expressão que se dá em sua forma sensível que é a própria paixão, ligada à sensibilidade, e, outra que "não surge subitamente; ela nasce de uma contemplação assídua do objeto amado"11. Esta segunda expressão dá-se no apetite intelectual que de fato, para ele, "comporta uma certa união afetiva entre o que ama e o que é amado, enquanto considera a este como, de certo modo, unido a si ou a si pertencente e, por isso, move-se para ele"12.

A análise tomasiana sobre a união afetiva possui uma impostação de caráter mais ontológico. Contudo, hoje convém fazer uma aproximação fenomenológica ${ }^{13}$ que possibilite uma abordagem mais personalista da história de vida das pessoas com suas constantes variações, altos e baixos. A perspectiva adotada por Santo Tomás, embora ontológica, contém em sua forma dinâmica uma abertura para a experiência vivida do sujeito. O papa Francisco, na exortação, captou esta sensibilidade no real com o que a pessoa vive sua união afetiva.

Portanto, para Santo Tomás, o ato de caridade não é apenas a benevolência mas também uma união afetiva. O papa Francisco, ao fazer esta citação do teólogo dominicano, quer afirmar e demonstrar que na profunda experiência de amor humano é possível chegar a um nível de união afetiva tal que faz subsistir em meio a certas experiências passageiras de paixão. Todo ser humano e o casal em particular, na

\footnotetext{
${ }^{10}$ Assim se exprime o texto na sua versão latina: “(...) benevolentia proprie dicitur actus voluntatis quo alteri bonum volumus".

${ }^{11}$ Assim se exprime o texto na sua versão latina: “(...) quod non subito exoritur, sed per aliquam assiduam inspectionem rei amatae".

${ }^{12}$ Assim se exprime o texto na sua versão latina: “(...) Importat enim quandam unionem secundum affectus amantis ad amatum: inquantum scilicet amans aestimat amatum quodammodo ut unum sibi, vel ad se pertinens, et sic movetur in ipsum

${ }^{13}$ Esta perspectiva pode ser encontrada em BERNARD, 1985, p. 127-128.
} 
caridade conjugal, é chamado a percorrer um itinerário progressivo de amor que tende a se aprofundar quando ambas as partes se entregam em uma experiência amorosa de profundidade ${ }^{14}$. $\mathrm{O}$ amor de benevolência é uma expressão da caridade que conduz a um verdadeiro caminho de amizade, tão necessário à vida conjugal. Esta experiência de conjugalidade que emana desta união afetiva é geradora de alegria no coração do casal e dos filhos.

Nota 122: esta citação de Santo Tomás ainda trata acerca do amor, contudo em outra obra (SCG. III, 123; ARISTÓTELES, 1984, p. 174). A perspectiva de fundo é a de que depois do amor que une a Deus, o amor conjugal é a "amizade maior" (AL, n. 123). Aqui encontramos a grande originalidade do pensamento do teólogo dominicano. Ao partir da ideia de que a vida conjugal é uma experiência de amizade maior, Santo Tomás apresenta a sua visão otimista sobre a vida conjugal e o amor que possibilitou à tradição cristã superar certa ideia 'reducionista' segundo a qual a intimidade ou o amor conjugal (ato conjugal) destinava-se única e exclusivamente à prole ou procriação ${ }^{15}$.

Para Vidal (2007, p. 51), a abordagem de Santo Tomás, no que se refere ao amor conjugal como máxima amizade reflete uma notável originalidade teórica e uma grande sensibilidade prática. Para ele, a sacramentalidade do matrimônio assume esta amizade que tende a se tornar maior à medida que o casal viva de forma intensa a união afetiva. Para Schillebeeckx (1969, p. 267), a sacramentalidade dá-se justamente nesta amizade maior como uma expressão da graça presente no amor conjugal.

A visão do Aquinate sobre o matrimônio como "amizade maior" (ou "maxima amicitia") antecede à ideia que foi mais disseminada com relação ao fim primeiro e secundário do matrimônio. Santo Tomás prefere dizer que o matrimônio possui três bens (prole, fé e sacramento), sendo um sinal visível (sacramentum) na Igreja (TOMÁS, SCG, III, 123, t. II). Para ele,

(...) a amizade, quanto maior é, mais firme e duradoura. Suma amizade ("maxima amicitia") parece existir entre o marido e a mulher, uma vez que não só se unem no ato da cópula carnal, que entre os próprios animais causa sociedade prazerosa, mas também no consórcio de toda a vida doméstica, cujo sinal é que o homem por causa da mulher 'deixa seu pai e sua mãe' (Gn 2,24). É,

\footnotetext{
${ }^{14} \mathrm{~A}$ abordagem tomasiana sobre o amor é complexa, pois sintetiza uma perspectiva ontológica (da ordem do ser na pessoa) mas também se abre a uma abordagem fenomenológica (dinâmica existencial). Sobre este tema, convém notar a contribuição da reflexão de MENESES, 2000, p. 55-70. No capítulo primeiro da segunda parte do livro, intitulado "A comunhão existencial do amor" apresenta a ideia de união afetiva de forma a integrar os aspectos ontológico e fenomenológico, a partir da tese de Rousselot.

${ }^{15}$ Esta reflexão também pode ser aprofundada e melhor refletida em NOONAN, in: VV.AA., 1977, p. 344-351.
} 
portanto, conveniente que o matrimônio seja totalmente indissolúvel (TOMÁS, SCG, III, 123, t. II) ${ }^{16}$.

A visão do matrimônio como um amor de amizade maior é compreensível dentro do horizonte segundo a qual a experiência de amizade supõe a "igualdade" (TOMÁS, SCG, III, 123, t. II) ${ }^{17}$ entre o homem e a mulher. De fato, o mundo contemporâneo é mais sensível à ideia de que o vínculo matrimonial esteja mais assentado sobre esta experiência real de igualdade entre o homem e mulher. Para o papa Francisco, esta visão de Santo Tomás, uma antropologia teológica positiva, possibilita repensar a tese clássica da indissolubilidade mais na inclinação afetiva recíproca que no contrato jurídico. Embora ambas as dimensões não estejam em oposição, convém teológica e pastoralmente hoje acentuar esta dimensão do amor conjugal $^{18}$ como amizade maior, fundamento da visão de conjugalidade contemporânea.

Nota 127: esta citação coloca-se de forma positiva no sentido de que no matrimônio convém cuidar da alegria do amor. A menção a Santo Tomás aqui refere-se à perspectiva de que a alegria é capaz de dilatar a amplitude do coração (TOMÁS, S.Th. I-II, q. 31, art. 3, ad 3). Esta ideia do teólogo dominicano situa-se na questão 31 "O deleite ou prazer em si mesmo" ("De delectatione secundum se"). $\mathrm{O}$ artigo $3^{\circ}$, de onde o papa Francisco se inspira para fundamentar a sua afirmação, trata da seguinte pergunta feita por Santo Tomás: “O prazer difere da alegria?" ("Utrum delectatio differat a gaudio"). Santo Tomás preocupa-se em dizer que o prazer pode se tornar alegria nos seres dotados de razão.

O tema da alegria em Santo Tomás aparece junto com o lúdico ${ }^{19}$. O papel que o lúdico adquire em sua ética decorre de sua própria concepção de moral: a moral é o ser humano. Neste sentido, o ser humano é e está chamado a ser. Se a moral é um processo de auto-realização, esta se dá à

\footnotetext{
${ }^{16} \mathrm{O}$ texto latino assim se exprime: "Amicitia, quanto maior, tanto est firmior et diuturnior. Inter virum autem et uxorem maxima amicitia esse videtur: adunantur enim non solum in actu carnalis copulae, quae etiam inter bestias quandam suavem societatem facit, sed etiam ad totius domesticae conversationis consortium; unde, in signun huius, homo propter uxorem 'etiam patrem et matrem dimittit, ut dicitur (Gen. 2,24). Conveniens igitur est quod matrimonium sit omnino indissolubile". ${ }^{17}$ A versão latina do texto afirma esta ideia de igualdade, baseado no comentário à Ética à Nicômaco de Aristóteles, do seguinte modo: "Amicitia in quadam aequalitate consistit".

${ }^{18}$ Esta ideia do amor conjugal foi citado na Constituição Pastoral Gaudium et Spes, n. 49, quando assim diz: “(...) Esse amor, eminentemente humano, afeição voluntária de um para com o outro, abraça a pessoa na sua totalidade, conferindo especial dignidade e nobreza às expressões de afeto, inclusive corporais, como elementos e sinais da amizade conjugal". A própria exortação apostólica $\mathrm{AL}, \mathrm{n} .125$ admite que o texto da GS, nn. 49 e 50 são textos maduros que colocam o amor como amizade no centro da vida conjugal do casal e da família.

${ }^{19}$ Sobre esta abordagem, vale a pena aprofundar a relação entre o lúdico e a alegria em Santo Tomás a partir de LAUAND, v. 1, 2007. No primeiro capítulo, intitulado "Deus ludens - o lúdico no pensamento de Tomás de Aquino e na pedagogia medieval" (p. 15-37), o autor faz uma sintética relação entre a alegria enquanto virtude o sentido do ludens.
} 
medida que a alegria seja uma experiência ligada ao amor (TOMÁS, S.Th. II-II, q. 169, art. 3, ad. 3) ${ }^{20}$. Para Santo Tomás, a alegria do amor está relacionada a esta necessária condição humana de refazer as forças interiores. $\mathrm{O}$ prazer se tornando alegria, dilata o coração enchendo-o de sentido, e, alegrando também a vida matrimonial (TOMÁS, S.Th. I-II, q. 31, art. 3, ad $3{ }^{21}$. O papa Francisco insiste nesta ideia, também já aludida no Vaticano II (GS, n. 48) na qual a profundidade do amor matrimonial assume a alegria que, interpretando Santo Tomás, é causado pela presença do bem amado e do fato que o bem amado possui este bem. Então, a vida matrimonial é "Amoris Laetitia" à medida que se assume a totalidade da experiência da caridade que tem a sua fonte em Deus e no bem do homem e da mulher. Encontramos nesta citação uma fundamentada antropologia teológica tão necessária para repensar a moral matrimonial em sua expressão de virtude cristã, sem reduzi-la à forma canônica.

Nota 129. A referência "o amor de amizade chama-se 'caridade', quando capta e aprecia o 'valor sublime' que tem o outro" (AL, n. 127), encontra-se na questão 26 (TOMÁS, S.Th. I-II) "O amor" ("De passionibus animae in speciali. Et primo, de amore"), no artigo 3o "Amor é o mesmo que dileção?" ("Utrum amor sit idem quod dilectio"). Ela pode ser considerada como o início da compreensão que Santo Tomás tem do ser humano e da sua moral. Ela faz parte do tratado das "Paixões da alma" (TOMÁS, S.Th. I-II, q. 22-48) 22. Para ele, o ser humano possui três apetites: o natural, o sensível e o da inteligência. Ele faz um estudo pormenorizado destas realidades humanas que interferem nas escolhas da pessoa. O papa Francisco capta o sentido que o teólogo medieval quer exprimir quando compreende que a caridade, uma forma de amor sublime, que vai além de experiências fragmentadas e unicamente prazerosas, é uma modalidade inteligente, pois supõe que o sujeito se eleve a uma condição 'sublime' do outro ${ }^{23}$.

Para Santo Tomás, que distingue as quatro palavras - amor, dileção, caridade e amizade -, o modo de amar próprio da caridade capta o sentido

\footnotetext{
20 "Ludus est necessarius ad conversationem humanae vitae".

${ }^{21}$ A versão latina completa da nota 127 diz o seguinte: "Ad tertium dicendum quod alia nomina ad delectatione pertinentia, sunt imposita ab effectibus delectationis: nam laetitia imponitur a dilatatione cordis, ac si diceretur laetitia; exultatio vero dicitur ab exterioribus signis delectationis interioris, quae apparent exterius, inquantum scilicet interius Gaudium prosilit ad exteriora; iucunditas vero dicitur a quibusdam specialibus laetitiae signis vel effectibus. Et tamen omnia sita nomina videntur pertinere ad gaudium: non enim utimur eis nisi in naturis rationalibs.

${ }^{22}$ Este tratado "De Passionibus" é uma das formas pelos quais o teólogo dominicano busca compreender o agir humano e as suas circunstâncias atenuantes. Ele as estuda a partir das fontes que tinha em mãos, tais como: a Escritura, os Padres da Igreja, Alberto Magno seu mestre e Aristóteles. Com o advento da psicologia e da psicanálise, a partir do séc. XIX, esta perspectiva naturalista foi sendo substituída por uma científica que ajudou-nos a compreender melhor o funcionamento da psiquê e a complexidade da interioridade humana.

${ }^{23} \mathrm{O}$ texto na sua versão latina diz com precisão sobre a caridade: "Caritas autem addit supra amorem, perfectionem quandam amoris, inquantum id quod amatur magni pretii aestimatur, ut ipsum nomen designat" (TOMÁS, S.Th. q. 26), respondeo.
} 
sublime do outro. A caridade sendo uma inclinação afetiva recíproca que nasce da perfeita conformidade com o outro - a forma perfeita de amor gratuito - é entendida pelo papa como experiência de caridade ou amizade, sendo uma dimensão fundamental na vida conjugal. E mais: esta experiência de gratuidade que o casal é chamado a viver é o que dá alegria ao amor, elevando-o à ordem sacramental.

Nota 130: “(...) do amor pelo qual uma pessoa me é agradável, depende que the dê algo de graça" (TOMÁS, S.Th. I-II, q. 110, art. 1) ${ }^{24}$. Esta citação está em continuidade com a anterior, quando trata da experiência de amizade enquanto o que se capta de sublime no outro. Aqui, Francisco retoma Santo Tomás para dizer que este amor que vincula ao outro possui algo de belo, de estético. O papa, para solidificar a sua percepção, retoma o artigo $1^{\circ}$ da questão 110 sobre a "A essência da graça de Deus" ("De gratia dei quantum ad eius essentiam"). $\mathrm{O}$ artigo primeiro versa sobre a própria graça; eis como Santo Tomás a elabora: "A graça acrescenta algo à alma?" ("Utrum gratia ponat aliquid in anima").

O tratado da graça para o teólogo dominicano ocupa uma centralidade no seu pensamento. Coloca-se na parte moral, pois é analisada após o longo tratado dos atos humanos. Para Santo Tomás, a graça é abordada como um auxílio trazido por Deus ao homem para fazê-lo querer o que é bom e agir bem ${ }^{25}$. Para ele, na questão 110 , a graça é na alma um dom recebido de Deus, que penetra suas faculdades e o faz agir de forma virtuosa.

Na verdade, esta percepção tomasiana tinha sido já assimilada na chamada hermenêutica personalista (FINO, 2017, p. 68) do sacramento do matrimônio no Vaticano II, quando a retomada de uma ética das virtudes tendia a olhar a aliança conjugal como uma graça que exprimia a participação na vida trinitária. A graça é o próprio 'destino' da pessoa no horizonte divino. Este destino não está previamente traçado, mas é um processo propriamente humano, purificador das dimensões mais profundas da pessoa - consciência, liberdade e responsabilidade - que leva à capacidade de amar. Retomar o pensamento fecundo de Santo Tomás na exortação pós-sinodal AL faz-nos pensar que Francisco está consciente de que o amor conjugal, presente na profundidade dos cônjuges, não é meramente um amor humano (profundo, porém limitado), mas está fecundado pela vida da graça. Deus, presente com o seu ser que é amor na interioridade da vida e dos atos humanos, faz com que a pessoa e o casal, pelo desejo de união afetiva, retornem ao original amor que é integrador.

\footnotetext{
${ }^{24}$ A versão latina no seu todo parece ser mais precisa que a tradução feita para a língua portuguesa: “(...) quod dicitur aliquis habere gratiam hominis, intelligiur in aliquo esse aliquid quod sit homini gratum, sicut et in hoc quod dicitur aliquis gratiam Dei habere; sed differenter (...)". ${ }^{25} \mathrm{Na}$ Summa Theologiae, p. 839, Fr. Jean-Hervé Nicolas, OP, faz uma introdução muito sugestiva situando este tratado "De gratia" no todo do pensamento da própria Summa.
} 
A nota 130 de Santo Tomás em AL só pode ser compreendida à luz desta teologia da graça, segundo a qual, todo tipo de amor presente no coração humano - e de modo particular, o amor vivido pelos cônjuges - encontra no amor sobrenatural de Deus a sua fonte. Eis como o próprio Aquinate se exprime,

(...) segundo este amor Deus quer absolutamente à criatura o bem eterno que é ele mesmo. Assim, quando se diz que alguém possui a graça divina, compreende-se que há nesta pessoa algo sobrenatural que vem de Deus. Às vezes, entretanto, dá-se o nome de graça a este amor eterno de Deus (...) (TOMÁS, S.Th. I-II, q. 110) ${ }^{26}$.

Portanto, a menção de Francisco ao tratado da graça de Santo Tomás, ajuda-nos a compreender que a vida divina presente nos dinamismos e na complexidade do ser humano é capaz de ativar o amor humano presente na estrutura interior da pessoa humana. Assim, o papa demonstra uma refinada preocupação em não reduzir toda a realidade complexa do amor humano a uma antropologia racionalizante, mas dá-nos uma fundamentação teológica tomasiana para possibilitar uma visão de conjunto mais ampla em tempos de reducionismos.

Nota 135. No capítulo IV, "O amor no matrimônio", o papa Francisco ainda comentando o hino ao amor, utiliza um outro texto de Santo Tomás. Esta nota está presente na parte do capítulo na qual o pontífice desenvolve a ideia segundo a qual o amor possui uma dimensão gradual, de crescimento e de amadurecimento. A citação literal do texto está assim:

A caridade, devido à sua natureza, não tem um termo de aumento, porque é uma participação da caridade infinita que é o Espírito Santo (...). E, do lado do sujeito, também não é possível prefixar-lhe um fim, porque, ao crescer na caridade, eleva-se também a capacidade para um aumento maior (TOMÁS, S.Th. II-II, q. 24, art. 7) ${ }^{27}$.

A presente citação de Santo Tomás encontra-se na questão 24 "O sujeito da caridade" ("De caritatis subiecto"), no artigo 7ㅇ "A caridade aumenta infinitamente" ("Utrum caritas augeatur in infinitum"). Embora os desdobramentos no método tomasiano não estejam presentes na exortação, convém levar em consideração alguns elementos propositivos do nosso teólogo que subjazem ao texto. Ao analisar o sujeito da caridade, a preocupação

\footnotetext{
${ }^{26} \mathrm{Na}$ versão latina o texto assim se exprime: “(...) et secundum hanc dilectionem dicitur aliquem diligere simpliciter: quia secundum hanc dilectionem vult Deus simpliciter creaturae bonum aeternum, quod est ipse. Sic igitur per hoc quod dicitur homo gratiam Dei habere, significatur quiddam supernaturale in homine a Deo proveniens (...)".

${ }^{27} \mathrm{Na}$ versão latina há uma pequena variação do mesmo texto que diz: “(...) Ipsa enim caritas secudum rationem propriae speciei terminum augmenti non habet: est enim participatio quaedam infinitae, quae est Spirictus Sanctus. Similiter etiam causa augens caritatem est infinitae virtutis, scilicet Deus".
} 
central do Aquinate é a de apresentá-la como uma virtude, isto é, um hábito operativo bom.

A caridade em si, para Tomás, só pode ser conhecida pelo sujeito que vive em suas dimensões e faculdades humanas. A caridade, segundo esta perspectiva de Santo Tomás, é assumida na atualidade a partir de uma perspectiva personalista. Como o amor não tem um fim, todo amor origina-se para fora de nós mesmos (GENOVESI, 2008, p. 29). Este amor que não tem um fim, é puro crescimento, é o contexto onde a pessoa tem necessidade de ser acolhida e cuidada pelo amor do pais, podendo se tornar autônoma em um caminho gradual (CERETI, 2015, p. 12).

O papa Francisco, felizmente, ao tomar esta reflexão de Santo Tomás que insiste na gradualidade humana ${ }^{28}$ da vida do amor, enraíza esta caridade ou amor, tanto em Deus, como no sujeito que participa ativamente no ser de Deus. A caridade, neste sentido, tanto diz algo do ser de Deus, como também é uma virtude interior e operativa do ser humano.

Então, o pontífice, relendo o teólogo dominicano, preocupa-se em buscar na sua forma de fundamentar teologia e antropologia, uma perspectiva de maior complexidade à realidade do amor humano, entrando em sintonia com os avanços da nossa cultura contemporânea, sem se reduzir a uma única perspectiva.

Nota 140. Esta citação está também no capítulo IV que trata da influência das emoções na experiência de amor humano. O texto de Santo Tomás indicado na AL 145 diz que "experimentar uma emoção não é, em si mesmo, algo moralmente bom nem mau" (TOMÁS, S.Th. I-II, q. 24, art.1). Esta indicação do nosso teólogo dominicano foi extraída do tratado das "Paixões da Alma" (q. 22-48), questão 24 "O bem e o mal nas paixões da alma" ("De bono et malo in animae passionibus"), no artigo 1" "(Pode haver bem e mal moral nas paixões da alma?" ("Utrum bonum et malum morale possit in passionibus animae inveniri"). Francisco ao fazer uso desta concepção antropológica tomasiana retoma uma boa percepção antropológica e teológica dos atos humanos no nosso grande teólogo.

Santo Tomás tem clareza que as paixões, ou os movimentos apetitivos da alma, em sua realidade físico-psicológica, fazem parte de uma perspectiva pré-moral; só assume uma conotação propriamente moral na medida em que a dimensão reflexiva ou responsável do ato é assumido pelo sujeito.

${ }^{28}$ Esta ideia de gradualidade humana é algo marcadamente considerado na nossa cultura contemporânea. A visão de ética das virtudes de Santo Tomás proporciona uma reflexão dinâmica, prudencial e integrativa, que não se reduz apenas à normatividade e ao utilitarismo, mas a uma construção contínua já que a pessoa, por participar espiritualmente e intelectualmente do ser de Deus, também está em uma dinâmica infinita. Em BEDNARSKI, 1986, o autor apresenta uma boa análise da estrutura antropológica pensada por Santo Tomás, em diálogo com uma perspectiva personalista.

Perspect. Teol., Belo Horizonte, v. 50, n. 1, p. 135-161, Jan./Abr. 2018 
O fato de experimentar uma emoção, segundo a visão tomasiana de paixão, não é se lançar em uma situação que perturbará a totalidade da pessoa. Para ele, a semântica da palavra 'paixão' não tem um sentido pejorativo. Designa simplesmente o movimento da sensibilidade ${ }^{29}$. Ela começa com a mais leve impressão e se verifica em todo movimento afetivo, sentimento ou emoção.

O teólogo, profundo conhecedor da natureza humana, tinha a convicção já no século $\mathrm{XII}^{30}$ de que existe na interioridade humana dimensões irracionais (COTTIER, 1974, p. 91-123) (11 $^{1}$ ou não totalmente conhecidas ou 'dominadas' pelo sujeito ético. Quando Santo Tomás estuda as paixões da alma ele está consciente que há atos que são comuns ao homem e ao animal (TORREL, 2008, p. 315s). Para ele, nossas primeiras reações subjetivas começam no nível do apetite (ou da afetividade) sensível, isto é, no nível da tendência natural que inclina o ser vivo para o bem. Esta tendência natural se encontra também no nível intelectual, chamando-se vontade.

No nível da afetividade sensível, as reações se produzem em relação a bens ou males particulares, como que reações, que Santo Tomás chama de 'paixões', porque o sujeito, mais do que senhor delas, as sofre, fazendo parte de uma dimensão involuntária dos atos humanos. O fato de os casais viverem imersos em experiências emocionais, em uma gradual afirmação do amor, não é em si mesmo, segundo Francisco - citando São Tomás algo moralmente bom ou mau, mas um caminho de amadurecimento de toda pessoa que busca encontrar um alicerce seguro na vida a dois com os filhos no contexto familiar.

O papa, portanto, retomando à inteligência verificadora de Santo Tomás, quer afirmar que toda pessoa envolvida em uma relação matrimonial é chamada a integrar 'forças' involuntárias das 'paixões' da alma, em um itinerário de estabilidade na instituição familiar. Mais que apontar para um horizonte objetivista ou normativo, Francisco convida a Igreja a ter um olhar de discernimento para a progressiva experiência amorosa presente em toda pessoa.

\footnotetext{
${ }^{29}$ Esta análise foi estudada de forma mais sistemática por TORREL, 2008, p. 311-315.

${ }^{30}$ Sobre o tema do amor erótico, do afeto e de todas as paixões que influenciam o psiquismo humano há um importante estudo ainda por ser aprofundado, remontando à rica tradição antropológica medieval. Quem acenou para esta realidade foi LECLERCQ, 1983.

${ }^{31}$ Neste artigo, o autor faz uma interessante análise comparativa entre Freud e Santo Tomás, destacando que o teólogo dominicano medieval, por meio da categoria de 'appetitus' percebia que existia no ser humano dimensões irracionais que necessitavam ser integradas ao longo da vida, mediante uma vida virtuosa. Segundo Cottier, esta força interior - 'apetite natural' - segundo Santo Tomás, foi posteriormente desenvolvido na teoria freudiana de 'libido' e 'inconsciente'.
} 
Nota 141. Em continuidade ao capítulo IV, e tratando sobre o tema do "amor apaixonado", Francisco menciona esta citação (TOMÁS, S.Th. I-II, q. 59, art. 5), que na compreensão da Suma de Teologia refere-se à "Comparação da virtude moral com a paixão" ("De comparatione virtutis moralis ad passionem"). A concepção subjacente ao pensamento ético de Santo Tomás é a de que as paixões, sob a influência da razão, podem tornar-se a sede das virtudes. Francisco está desenvolvendo a perspectiva segundo a qual o amor apaixonado tende a amadurecer quando a vida emotiva dos seus membros segue uma verdadeira liberdade. Para Santo Tomás, o amor, em sua dimensão de paixão, segue um caminho de harmonia livre ${ }^{32}$. Torna-se uma virtude quando todos os membros de uma família se envolvem neste amadurecimento.

O amadurecimento dos membros de uma família depende muito quando as vontades particulares estão integradas com liberdade pelo amor ${ }^{33}$. Este não é um caminho fácil e simples. Este itinerário ardoroso dá-se em um horizonte pessoal, de ordenamento dos apetites, até o desabrochamento para com o outro, em um ambiente de acolhida e respeito.

O papa Francisco fundamenta a sua opção tomasiana no sentido de que "se uma paixão acompanha o ato livre, pode manifestar a profundidade dessa opção" (AL, n. 146). A ideia de emotividade é uma dimensão fundamental na vida humana e da família. Mas quando o papa Francisco fala em 'vida emotiva' na família, o que de fato ele quer dizer? Ele quer resgatar uma perspectiva de conjugalidade que é intrínseca à relação humana, isto é, o significado unitivo (GS, n. 49) ${ }^{34}$, fundamental no estreitamento dos laços entre os membros da família e gerador de alegria recíproca.

Nota 144. A presente citação de Santo Tomás (S.Th. I-II, q. 32, art. 7), ainda no capítulo IV, situa-se no contexto segundo a qual o papa Francisco fala sobre a educação da emotividade e do instinto para dar um equilíbrio ao prazer. A referência que ele tomou do Aquinate encontra-se no contexto em que se trata da causa do prazer ("De causa delectionis"), quando se propõe a responder a seguinte questão "A semelhança é causa de prazer?" ("Utrum similitudo sit causa delectationis").

Se na questão em seu todo Santo Tomás busca compreender o que causa o prazer, no artigo ele se questiona se a semelhança pode destruir o próprio prazer ou o bem. Ele chega à conclusão de que a ideia de

\footnotetext{
${ }^{32}$ Esta perspectiva é melhor explicitada e desenvolvida por MONDIN, 1991, p. 31-32. Neste verbete, o autor faz alusão à recíproca relação entre amor, paixão e afeição.

${ }^{33}$ Há uma boa síntese e aprofundamento feito por PÉ, 2004, p. 91-140. Revisitando a noção de appetitus e affectus em Santo Tomás, o autor associa com a moderna visão psicológica de afetividade e sexualidade com o seu desenvolvimento natural.

${ }^{34}$ Nesta indicação conciliar, retoma-se uma perspectiva medieval, anterior à disciplina canônica erigida em Trento, segundo a qual o amor e entrega mútuos são a base da posterior teoria da indissolubilidade.
} 
semelhança, por preservar a unidade, pode tanto ser um bem como preservar a integridade. Ele cita dois exemplos para mostrar que o prazer pode ser um bem: “(...) e se o que é semelhante não destrói o bem próprio, mas o aumenta, é absolutamente deleitável; por exemplo, o homem para o homem, o jovem para o jovem" (TOMÁS, S.Th. I-II, q. 32, art. 7) ${ }^{35}$. Para Santo Tomás, o prazer necessita ser reordenado em um horizonte de unidade da pessoa onde se busca a semelhança. O papa Francisco, na esteira da boa tradição tomasiana ${ }^{36}$ assevera que o prazer não é um inimigo do ser humano, mas necessita ser integrado, superando o excesso, o descontrole e a obsessão.

A busca por um processo educativo da emotividade e do instinto é um caminho muito importante em Santo Tomás. Na verdade, esta é a grande característica do pensamento do teólogo, quando se propõe a integrar a natureza e a cultura mediante um processo de vida virtuosa (TORREL, 2008, p. 315s). Educar a emotividade e o instinto é o grande mérito de uma ética das virtudes que também se propõem a elevar o ser humano " $a$ ser tal como Deus nos fez" (MARTÍNEZ, 2004, p. 80). Na vida matrimonial, há a possibilidade de amadurecer este itinerário formativo com o fim de ajudar seus membros a se integrarem na harmonia do amor.

Sendo assim, segundo Francisco é possível fazer um processo educativo e positivo com as paixões, o que significa orientá-las cada vez mais em um projeto de autodoação e plena realização que enriquece as relações interpessoais. O papa, munido desta positiva antropologia, prefere falar antes em um caminho integrativo que punitivo ou rigorista. Santo Tomás (S.Th. I-II, q. 24, art. 3), portanto, se afasta da tendência estoica, mais propensa ao rigorismo psicofísico que influenciará a tradição, aprofundando em uma verdadeira psicologia dos atos e das paixões em busca da vida virtuosa ${ }^{37}$.

Nota 145. Esta citação dentro da exortação pós-sinodal é a continuidade da anterior, sobre o tema da integração do prazer em um amor que gera alegria. A referência que o papa Francisco realiza (TOMÁS, S.Th. II-II, q. 153 , art. 2, ad 2$)^{38}$ coloca-se em uma valorização da experiência do amor e do prazer na vida do casal e da família, afastando-se de certa tendência

\footnotetext{
${ }^{35}$ Respondeo: "Et si quidem id quod est simile, proprium bonum non corrumpat, sed augeat, est simpliciter delectabile: puta homo homini, et iuvenis iuveni".

${ }^{36}$ Neste sentido é recomendável a boa análise na obra de PLÉ (1980). A mesma obra foi traduzida para o português: Por dever ou por prazer? São Paulo: Paulinas, 1984. No segundo capítulo da segunda parte, "Une morale du plaisir?" (PLÉ, 1980, p. 135-145), o autor faz uma excelente reflexão sobre a positiva visão de prazer integrado no cristianismo, desconhecida em grande parte, devido a certa desconfiança rigorista. Plé retoma a delectatio de Santo Tomás, indicando a sua necessária reinterpretação hoje.

${ }^{37}$ Este tema também é analisado em um bom intérprete contemporâneo de Santo Tomás em TORREL, 2008, p. 303-330 (capítulo 11: "Uma ideia do homem").

38 "Abundantia delectationis quae est in actu venereo secundum rationem ordinato, non contrariatur medio virtutis".
} 
rigorista que se afirmou no cristianismo, por influência estoica, impedindo que desabrochasse uma perspectiva positiva e integradora.

A citação que se faz de Santo Tomás encontra-se no conhecido tratado da Temperança ("De Temperantia"), na questão sobre o vício da luxúria ("De vitio luxuriae"), no artigo que tem a seguinte interpelação: "O ato sexual pode existir sem pecado?" ("Utrum aliquis actus venereus possit esse sine peccato"). A temperança para Santo Tomás é uma virtude que inclina o homem ao bem, ajudando-o a ter certa moderação ou comedimento introduzido pela razão às ações e paixões humanas (S.Th. II-II, q. 141, art. 2) ${ }^{39}$.

A citação do Aquinate presente em AL quer mostrar que não se perde a virtude simplesmente pelo fato de se fazer uma experiência de prazer pelos sentidos exteriores, mas tudo depende também do apetite interior. A preocupação de Francisco nesta reflexão dá-se pelo fato de que o verdadeiro amor supõe momentos de intenso prazer - o prazer propriamente sexual que gera intimidade - mas que esteja integrado com "outros momentos de dedicação generosa, espera paciente, inevitável fadiga e esforço por um ideal" (AL, n. 148). Esta perspectiva tomasiana vê o amor em sua visão positiva e menos rigorista.

Para Santo Tomás, o amor compreendido como uma virtude, integrada pela temperança, é capaz de favorecer um envolvimento do casal em um horizonte de gradual amadurecimento no amor e nas dimensões próprias da vida familiar. Mesmo que o prazer não faça parte do núcleo originário do querigma cristão, a suspeita do prazer se infiltrou na sucessiva reelaboração teológica do seu pensamento pelos influxos da filosofia estoica e das correntes maniqueístas (LEONE, 2004, p. 91).

A abordagem em AL, advinda de Santo Tomás, é de uma positiva antropologia que integra o corpo como o caminho do verdadeiro amor e alegria conjugal. Enquanto há tendências eclesiais ainda hoje que continuam disseminando uma perspectiva negativa sobre a profunda realidade do amor corpóreo-sexual, Francisco assume e integra no magistério de AL esta tradição antropológica e teológica de Santo Tomás que em pleno séc. XIII via o ser humano em sua positiva expressão de "capax amoris". $\mathrm{Na}$ verdade, a proposta erótico-ética do Aquino não se isola no eros enquanto força autônoma. É o amor, a força que atrai o eros para a integração que gera o dinamismo pessoal.

Nota 172. Esta referência de Santo Tomás (S.Th. II-II, q. 27, art. 1) na AL encontra-se também no capítulo IV. Nesta seção, o papa Francisco comentando acerca do matrimônio e a virgindade, salienta a importância de uma postura de virgindade casta por parte de casais ou pessoas casadas, que

${ }^{39}$ Respondeo: “(...) quia nomen temperantiae significat quandam temperiem, idest moderationem, quam ratio ponit in humanis operationibus et passionibus". 
quando o cônjuge se tornou fisicamente desagradável ou deixou de satisfazer as suas necessidades, cuida com afeto, manifestando um venerável amor. Nestas situações ele diz: "em semelhante amor, manifesta-se de forma esplêndida a dignidade de quem ama, dignidade como reflexo da caridade, já que é mais próprio da caridade amar do que ser amado" (AL, n. 62). Esta ideia acima situa-se no tratado da caridade ("De Caritate"), na questão sobre o ato principal da caridade: o amor ("De principali actu caritatis, qui est dilectio"), no artigo que tenta responder à interrogação: "É mais próprio da caridade ser amado, ou amar?" ("Utrum caritatis sit magis proprium amari quam amare"). Esta questão de Santo Tomás é central no seu pensamento. Para ele, tanto o celibato como o matrimônio encontram a sua fontalidade em um amor mais amante que desejoso de ser amado.

A percepção atual que se tem sobre o mistério da pessoa - em uma atual perspectiva fenomenológica - assumido pelo papa Francisco a partir do horizonte tomasiano, tem como referência a condição do ser humano. A identidade da pessoa estrutura-se sempre a partir de uma visão poliédrica, como um dom e uma tarefa, sendo por isso, uma identidade dramática (DIDONÈ, 2015, p. 146) ${ }^{40}$. Como um dom para viver a comunhão, a pessoa é chamada continuamente a integrar este desejo de amor para um fim. Tanto a experiência da oblatividade matrimonial como a do celibato advêm desta mesma estrutura dramática humana, fruto de um dom e de uma tarefa a ser realizada. O papa Francisco, retomando esta importante questão, quer afirmar que todo amor enraizado em Deus, fiel à própria interioridade humana - que move todas a forças recônditas do ser humano - conduz a uma experiência amorosa de oblatividade. O amor amadurecido e assumido enquanto um encontro de comunhão verdadeira direciona qualquer pessoa a uma entrega incondicional (CRISPIERO, 1994, p. 247-251) ${ }^{41}$, atualizando a experiência infinita e amorosa de Deus agindo no mundo. Toda a psicologia humana, estruturada não em si mesma, para o outro, encontra nesta expressão antropológica alegre, a possibilidade de amadurecimento e constantes discernimentos.

Notas 341 (TOMÁS, S.Th. I-II, q. 65, art. 3, ad. 2; De malo, q. 2, a. 2.), 342 (TOMÁS, S.Th. I-II, q. 65, art. 3, ad. 3.), 347 (TOMÁS, S.Th. I-II, q. 94, art. 4.) e $348^{42}$. Estas quatro citações encontram-se no capítulo VIII da exortação "Acompanhar, discernir e integrar a fragilidade", tão polemizado. No

\footnotetext{
${ }^{40}$ DIDONÈ, Stefano. "Fenomenologia della coscienza e stile cristiano. Approccio teologico-fondamentale". In: MARCATO, Michele (a cura). La coscienza in dialogo. Un approccio interdisciplinare. Studio Teologico Interdiocesano di Treviso - Vittorio Veneto. Padova: Messaggero di Sant'Antonio, 2015, 146.

${ }^{41} \mathrm{O}$ autor, nestas páginas, analisa a que Santo Tomás estava convencido de que a forma mais nobre de caridade encontra na oblatividade a sua expressão de comunhão trinitária. Tanto o celibato como o matrimônio, embora sejam estados de vida distintos, encontram as suas motivações mais verdadeiras numa sincera "via caritatis".

${ }^{42}$ A nota refere-se à obra Sententia libri Ethicorum, VI, 6 - ed. Leonina, t. 47, 354.
} 
intuito de compreender melhor "as circunstâncias atenuantes no discernimento pastoral" (n. 301-303), como também "as normas e o discernimento" (n. 304306), Santo Tomás é resgatado e assimilado aqui como mestre da alma e da psique humana. As duas primeiras citações estão localizadas no seu tratado sobre os hábitos e as virtudes, na parte final, na qual ele faz uma "conexão das virtudes" ("De conexione virtutum"). A grande preocupação dele é a de apresentar uma antropologia positiva que qualifique a pessoa no seu bem agir, fonte da moralidade.

Santo Tomás, relendo Aristóteles, se convenceu de que com a caridade virtude das virtudes - infunde-se conjuntamente todas as virtudes morais, pois Deus não age menos perfeitamente nas obras da graça do que nas obras da natureza ${ }^{43}$. Esta perspectiva muito ainda pertinente foi assimilada pela AL com o intuito de compreender o necessário discernimento a ser feito nas chamadas situações "irregulares".

Para além de uma simples solução canônico-jurídica, Francisco, embasado na autoridade teológica de Santo Tomás, percebe que a Igreja possui de fato uma sólida reflexão sobre os condicionamentos e as circunstâncias atenuantes (AL, n. 301). Santo Tomás alude para o fato de que há pessoas que mesmo tendo a graça e a caridade, podem ser incapazes de exercitar-se bem nas virtudes. Ele também se refere a alguns santos que mesmo não tendo algumas virtudes, possuem hábitos que possibilitam viver a caridade.

Para Francisco, há muitos casais e pessoas que conhecem bem a norma, mas podem ter dificuldade em compreender ou interiorizar os valores inerentes à norma. Sendo assim, precisam de um acompanhamento. A perspectiva em questão, de uma moralidade baseada nas virtudes, e, não meramente na legalidade canônica, segundo ele, precisa ser aprimorada diante da mudança de paradigma em que vivemos. A Igreja, os pastores e o próprio povo de Deus precisam ter a capacidade de assimilar esta perspectiva de acompanhamento (AZPITARDE, 1997, p. 229-239) ${ }^{44}$. Não se trata simplesmente de aplicar normas e enquadrá-las como ideal, mas de aprimorar moralmente a capacidade de discernir a partir das situações reais, em um horizonte de vida virtuosa.

Esta perspectiva é endossada de modo mais decisivo no n. 304. Nestas últimas duas citações de Santo Tomás, o papa Francisco considera que

\footnotetext{
${ }^{43}$ A ideia pode ser encontrada na S.Th. II-II. q. 65, art. 3, respondeo: “(...) cum caritate simul infunduntur omnes virtutes morales. Cuius ratio est quia Deus non minus perfecte operatur in operibus gratiae, quam in operibus naturae".

${ }^{44}$ Nesta reflexão, o autor acena para uma dimensão bíblico-teológica que necessita sempre ser lembrada. Para Paulo, em seu evangelho da liberdade, a libertação da lei impõe-se como exigência ineludível para viver nossa condição de pessoas e cristãos. Porém, sobretudo, quando se procura descobrir seriamente a vontade de Deus para tomar decisões, nem a moral e nem a lei constituem o melhor modo de alcançar esse objetivo. Somente um discernimento espiritual autêntico capacita verdadeiramente para vivermos a liberdade trazida por Cristo.
} 
uma verdadeira imagem cristã de ser humano - antropologia cristã e teológica - deve levar em consideração, na atual mudança de paradigma, o discernimento ${ }^{45}$, como caminho ético do viável. De fato, da citação de Santo Tomás, podemos compreender que há uma proposta do papa para que se exercite a virtude da prudência pastoral, fornecendo às pessoas elementos úteis para o intransferível processo de discernimento. A nota 347, citando Santo Tomás, trata sobre o discernimento; ela se encontra na questão dedicada à "Lei Natural" ("De Lege Naturali") (TOMÁS, S.Th. I-II, q. 94, art. 4) ${ }^{46}$. O artigo $4^{\circ}$ questiona: "a lei da natureza é uma em todos?" ("Utrum lex naturae sit una apud omnes"). Santo Tomás, no respondeo, faz uma longa distinção entre a razão especulativa (ratio speculativa) e a prática (ratio practica). Enquanto que na especulativa acha-se a verdade, na prática trata-se das coisas contingentes. Nesta complexidade da particularidade, própria da razão prática, é que se encontra a necessidade do discernimento.

O tema do discernimento teve certa visibilidade, antes, durante e depois do sínodo, com o objetivo de melhor compreender as situações reais e o necessário acompanhamento dos divorciados recasados. Qualquer solução nesta delicada área é uma tentativa de superar certo dualismo que a disciplina eclesial assinala em defesa da objetividade doutrinal, mas que também é necessário não minimizar a consciência pessoal da subjetividade moral ${ }^{47}$. Vemos que o retorno à teologia tomasiana, em sua antropologia teológica, sobre as situações atenuantes e o discernimento, vem redimensionar o excesso de objetivismo que se impôs na tentativa de solucionar os casos particulares. Um retorno à teologia de Santo Tomás, como salientamos neste artigo, é imprescindível para acentuar um necessário reequilíbrio entre doutrina e práxis canônica, iluminada por uma antropologia teológica.

A lei natural em Santo Tomás, não é, como muitos pensam, um "catálogo de preceitos deduzidos infalível e inevitavelmente uma vez por todas e para todos" (CHIAVACCI, 1997, p. 692), mas antes a capacidade que a pessoa tem de encontrar o preceito operativo concreto que melhor realize os valores expressos pelos preceitos mais gerais. Esta citação, muito bem escolhida, articula certa conflitualidade existente entre norma e discernimento, muito comum para os moralistas. Não se trata de interpretar a questão como mera atitude de "bonismo" do magistério para com as pessoas em situações irregulares, mas de assumir uma boa antropologia teológica que encontra na "via caritatis" (AL, n. 306) a busca por uma prudência em qualquer situação concreta.

\footnotetext{
${ }^{45}$ Sobre esta indicação ético-pastoral há já uma boa proposta em MELINA, 2016.

${ }^{46} \mathrm{Na}$ estrutura da I-II, após analisar detidamente os hábitos e as virtudes; os dons do Espírito Santo os vícios e os pecados, Santo Tomás, dedica à "pedagogia divina pela lei".

${ }^{47}$ Sobre este tema, ver FUMAGALLI, 2014, p. 138-159.
} 
A antropologia tomasiana que compreende todas as dimensões racionais e volitivas (vontade, psiquismo e agir moral), encontra na sua teologia espiritual e mística sua expressão mais alta. Este paradigma assumido no interior da exortação convida-nos a uma mudança de consciência ${ }^{48}$ como também de horizonte de acompanhamento das pessoas reais. Santo Tomás, assim, assumido e integrado na $\mathrm{AL}$, proporciona uma problematização mais refinada e sofisticada no campo da moralidade conjugal e familiar, ainda em processo de aprofundamentos ulteriores.

\section{Conclusão}

A reflexão que nos propusemos a fazer "Santo Tomás de Aquino na Amoris Laetitia: em busca de antropologia teológica da alegria" quis ser uma interpretação que salientasse as frequências, incidências e assimilação do autor em suas dezenove perspectivas distintas. Percebemos que o pensamento de Santo Tomás foi resgatado no corpo da exortação de modo mais visível no capítulo IV, quando o tema do amor teve seu realce. Também no capítulo VIII quando se trata do discernimento. Vemos que em pleno século XXI, um teólogo medieval tem muito a dizer a nós contemporâneos sobre o amor, o discernimento e a alegria. As duas sessões do sínodo muito ajudaram o sensus fidelium na busca por uma alegria do amor.

Propomo-nos a analisar o fato de que na fase pós-conciliar não houve um devido desdobramento aprofundado, no que se refere à moral matrimonial, em afrontar a condição real da família no mundo contemporâneo a partir de uma práxis que encontrasse no discernimento e acompanhamento a solução dos dramas inerentes da vida familiar. A retomada do teólogo dominicano Tomás de Aquino no corpo da AL comprova que há uma mudança de postura - teológica e moralmente - por parte do magistério de Francisco, em afrontar as situações particulares, não simplesmente segundo os procedimentos canônicos, mas a partir de uma perspectiva de acompanhamento e discernimento.

As ricas e profundas menções do Aquinate na exortação pós-sinodal sobre o tema do amor e da caridade devem ser o referencial concreto e real na busca das situações mais difíceis a serem afrontadas. Se um dos objetivos do pontífice, após ouvir atentamente as intervenções de todas as ordens, foi o de apresentar o matrimônio mais como um caminho dinâmico de crescimento e realização do que como um fardo a carregar a vida inteira, Francisco, a partir das referências a Santo Tomás, priorizou - mediante o

${ }^{48}$ Desenvolvi esta ideia de forma mais analítica em ALMEIDA, 2017, p. 520-535. 
caminho sinodal - a retomada de uma antropologia teológica da alegria como meio de discernimento para a experiência vivida das pessoas.

O magistério passa a exercer, neste sentido, a função de diaconia rumo à verdade, e, não, simplesmente, um repetidor da verdade já estabelecida a ser acolhida na consciência pessoal. Cabe a cada casal e família - no pleno sentido do sensus fidelium - buscar in Ecclesia, um acompanhamento honesto e verdadeiro dos ministros, servidores da verdade pelo discernimento. A Igreja passa a ser a testemunha da verdade que orienta seus filhos a aprender usar a consciência como adultos na fé em meio aos dramas da vida. Esta mudança de postura moral na AL é de fato solidificada na boa tradição ético-teológica de Santo Tomás que ainda tem muito o que contribuir para uma antropologia teológica da alegria. A normatividade canônica continua tendo o seu valor quando conseguir superar o tradicional dualismo: verdade objetiva e subjetividade da consciência. A assimilação de Tomás de Aquino no magistério de Francisco repropõe uma salutar interpretação sobre o sentido da complexidade e do amadurecimento do amor humano.

Vemos que a hermenêutica teológica em torno de Santo Tomás na exortação foi uma opção pertinente diante do atual quadro de uma sociedade complexa. A sociedade do futuro o será ainda mais. As questões morais serão também complexas. Neste sentido, a perspectiva ético-teológica do dominicano permite dialogar com um novo contexto pluralista que se impõe, sem perder o fundamento tradicional em contínua transição. $\mathrm{O}$ fato de termos hoje novas configurações familiares que se distinguem do modelo tradicional leva-nos a buscar um tratamento ou abordagem, sem a audácia de querer dar uma única solução aos questionamentos morais. Respostas tradicionais sem o devido acompanhamento poderão se tornar vazias ou obsoletas. Refugiar-se na antiga normatividade também tende a se tornar uma proposta antiquada. Encontramos na epistemologia dialética e dialogante de Santo Tomás, bem articulada na $\mathrm{AL}$, um esforço do magistério eclesiástico em colocar-se diante de uma proposta de caminho a ser percorrido. A exortação, de qualquer modo, enriquecida com a impostação tomasiana, lança a oportunidade de recuperar uma tradição de ética das virtudes que tenta articular a provisoriedade criativa e paciência histórica, junto às situações particulares. A sabedoria concreta de Santo Tomás (prudência), articulada com a tradição do amor fecundo (dimensão bíblica), devolvem à sacramentologia matrimonial o seu ímpeto teológico e pastoral.

Há muito ainda a dialogar, discutir e ouvir sobre a realidade do amor, a alegria do amor divino-humano e os vários discernimentos a serem feitos na comunidade eclesial. Mais que gerar uma reviravolta na forma de abordar o sacramento do matrimônio e a questão da família, este importante texto do magistério ordinário pontifício, remonta a um teólogo 
que soube, como nenhum outro, olhar a realidade humana em uma ótica teológica, buscando dar certa razoabilidade ao mistério da fé. Retomar o pensamento de Santo Tomás é sempre um imperativo necessário à Igreja em momentos de debates em torno dos fundamentos do ato de crer e de viver. A sua teologia, equilibrada no método e na epistemologia, está também profundamente arraigada no Deus comunhão trinitária que se revela. Sua antropologia e psicologia ainda por ser estudada e confrontada com os novos saberes modernos e desdobramentos contemporâneos, provoca-nos na busca por um amor que se exprime em sua alegria.

Retomar o pensamento tomasiano em uma exortação pós-sinodal possibilita articular uma proposta moral na qual se distingam dois tipos de orientações: os princípios gerais e as aplicações concretas. Resguarda a dimensão propriamente doutrinal - enquanto tradição viva - as devidas aplicações concretas não possuirão o mesmo grau de verdade e por isso não pedirão a mesma profundidade e amplitude de assentimento. A antropologia teológica que brota do pensamento enriquecedor de Santo Tomás se assoma ao fato que ele apontou, em pleno século XIII, o desejo alegre em buscar a Deus, redimensionando toda a estrutura humana pela ordem da graça.

A realidade familiar no atual contexto contemporâneo necessita de uma compreensão que passe pelo horizonte de um amor alegre. Eis o convite de Francisco a toda a Igreja e às famílias. Eis o nosso desafio de estudar e aprofundar a realidade humana com as suas ricas expressões de significado.

\section{Referências}

ALMEIDA, A. L. B. O discernimento da consciência na Exortação Apostólica Amoris Laetitia. Revista Eclesiástica Brasileira, Petrópolis, v. 77, n. 307, p. 520-535, jul./set. 2017.

ARENDT, H. O conceito de amor em Santo Agostinho: ensaio de interpretação filosófica. Lisboa: Instituto Piaget, 1997.

ARISTÓTELES. Ética a Nicômaco. Oxford: Bywater, 1984.

AZPITARDE, E. L. Discernimento Moral. In: COMPAGNONI, F.; PIANA, G.; PRIVITERA, S. Dicionário de Teologia Moral. São Paulo: Paulus, 1997. p. 229-239.

BEDNARSKI, F. A. L'educazione dell'affettività alla luce della psicologia di S. Tommaso D'Aquino. Milano: Massimo, 1986.

BERNARD, C. A. Teologia affettiva. Milano: Paoline, 1985. (Prospettive Theologiche $-6)$.

BOZZOLO, A. et al. Famiglia e Chiesa un legame indissolubile: contributo interdisciplinare per l'approfondimento sinodale. Roma: Libreria Editrice Vaticana, 2015. (Famiglia e Vita). 
CERETI, G. Matrimonio e misericordia: divorzio, nuove nozze e prassi della Chiesa. Bologna: Dehoniane, 2015.

CHIAVACCI, E. Lei Natural. In: COMPAGNONI, F.; PIANA, G.; PRIVITERA, S. Dicionário de Teologia Moral. São Paulo: Paulus, 1997. p. 690-791.

CONCÍLIO ECUMÊNICO VATICANO II. Mensagens. Discursos. Documentos. Constituição Pastoral Gaudium et Spes. São Paulo: Paulinas, 2007.

CONCÍLIO VATICANO II. Mensagens, discursos e documentos. São Paulo: Paulinas, 2017.

COTTIER, G. 'Libido' de Freud et 'appetitus' de Saint Thomas'. In: LUYTEN, N. A. L'antropologie de Saint Thomas. Fribourg: Editions Universitaires, 1974. p. 91-123.

CRISPIERO, M. Teologia della sessualità: approfondimenti sui temi de matrimonio e della verginità. Bologna: Edizioni Studio Domenicano, 1994.

DIDONE, S. Fenomenologia della coscienza e stile cristiano. Approccio teologico-fondamentale. In: MARCATO, M. (a cura). La coscienza in dialogo: un approccio interdisciplinare. Studio Teologico Interdiocesano di Treviso - Vittorio Veneto. Padova: Messaggero di Sant'Antonio, 2015. p. 146.

FINO, C. La sacramentalité du mariage. Enjeux et défis pour la théologie morale. La Maison-Dieu, Paris, v. 289, n. 3, p. 67-79. nov. 2017.

FRANCESCO. Amoris Laetitia. Esortazione apostólica postsinodale sull'amore nella famiglia. Testo integrale e comento de "La Civiltà Cattolica". Milano: Ancora Editrice, 2016.

FUMAGALLI, A. Il tesoro e la creta: la sfida sul matrimonio dei cristiani. Brescia: Queriniana, 2014.

GENOVESI, V. J. Em busca do amor: moralidade católica e sexualidade humana. São Paulo: Loyola, 2008.

LAUAND, J. Filosofia, Linguagem, Arte e Educação: 20 conferências sobre Tomás de Aquino. São Paulo: Factash, 2007. (Coleção Humanidades, v. 1).

LECLERCQ, J. Le mariage vu par les moines au XII siècle. Paris: Les Editións du Cerf, 1983.

LEONE, S. Educar para a sexualidade. São Paulo: Ave-Maria, 2004.

MARTÍNEZ, E. Ser y educar: fundamentos de pedagogía tomista. Bogotá: Universidad Santo Tomás, 2004.

MELINA, L. (a cura di). Quale pastorale familiare dopo Amoris Laetitia. Siena: Cantagalli, 2016 (Studi sulla persona e la famiglia - Atti Collana pubblicata in collaborazione con il Pontificio Istituto Giovanni Paolo II per Studi su Matrimonio e Famiglia).

MENESES, P. G. de. O conhecimento afetivo em Santo Tomás. São Paulo: Loyola, 2000.

MONDIN, B. Amore. In: Dizionario Enciclopedico del pensiero di San Tommaso D'Aquino. Bologna: Edizioni Studio Domenicano, 1991. p. 31-32.

NOONAN, J.T. Maxima amicita. In: VVAA. L'agire morale. Atti del Congresso Internazionale: Tommaso d'Aquino nel sua VII Centenario (17-24 aprile 1974). Napoli, 1977. p. 344-351. 
PÉ, A. M. Antropología de la afectividad. Navarra: Ediciones Universidad, 2004.

PÉREZ-SOBA, J. J. Il mistero della famiglia. Roma: Cantagalli, 2010.

PHILIPPE, M-D. O amor na visão filosófica, teológica e mística. Petrópolis: Vozes, 1999.

PLÉ, A. P. Par devoir ou par plaisir? Paris: Les Éditions du Cerf, 1980. Por dever ou por prazer. São Paulo: Paulinas, 1984.

ROCCHETTA, C. Teologia della famiglia: fondamenti e prospettive. Bologna: Dehoniane, 2011.

SCHILLEBEECKX, E. O matrimônio: realidade terrestre e mistério de salvação. Petrópolis: Vozes, 1969.

TOMÁS DE AQUINO. Suma Teológica. São Paulo: Loyola, 2005.

Summa contra gentiles. Tomo II. Madrid: Biblioteca de autores cristianos, 1953.

TORREL, J-P. Santo Tomás de Aquino: mestre espiritual. São Paulo: Loyola, 2008.

VESCO, J-P. Ogni amore vero è indissolubile: considerazioni in difesa dei divorziati risposati. Brescia: Queriniana, 2015.

VIDAL, M. O matrimônio: entre o ideal cristão e a fragilidade humana. Aparecida: Santuário, 2007. (Teologia, Moral e Pastoral).

Artigo submetido em 16.02.2018 e aprovado em 02.04.2018.

André Luiz Boccato de Almeida é doutor em Teologia Moral pela Pontifícia Universidade Lateranense de Roma (Academia Afonsiana - 2016). Pós-doutorando em teologia pela Pontifícia Universidade Católica do Paraná (PUC-PR). Professor de Moral Fundamental e Moral Sacramentária na Faculdade de Teologia da Pontifícia Universidade Católica de São Paulo (PUC-SP). Orcid.org/0000-0002-0547-5879. a.1.boccato@gmail.com

Endereço: Rua João de Santa Maria, 142

Jardim da Saúde

04158-070 São Paulo - SP 